\title{
PENGGUNAAN MODEL PEMBELAJARAN KONTEKSTUAL UNTUK MENINGKATKAN KEMAMPUAN PEMAHAMAN MATEMATIKA SISWA SEKOLAH DASAR
}

(Studi pada siswa kelas V SDN Sukarasa II Kecamatan Samarang

Kabupaten Garut Tahun pelajaran 2014-2015 )

Oleh :

Erik Santoso ${ }^{1}$ )

eriksantoso.math07@gmail.com

\begin{abstract}
ABSTRAK
Ketidakberhasilan peserta didik untuk memecahkan persoalan dalam pembelajaran dimungkinkan sebagai akibat pembelajaran yang dilaksanakan selama ini menggunakan strategi belajar mengajar dengan cara klasikal yaitu aktivitas di kelas di domonasi oleh guru, maka dari itu, guru harus pandai memilih metode, pendekatan, model pembelajaran dan teknik mengajar yang sesuai dengan materi yang akan diajarkan. Oleh karena itu, peneliti memilih pembelajaran dengan menggunakan model pembelajaran kontekstual. Rumusan masalah dalam penelitian ini adalah, apakah terdapat perbedaan kemampuan pemahaman matematik sebelum dan sesudah diberikan pembelajaran dengan model pembelajaran kontekstual? Hipotesis dalam penelitian ini adalah : "terdapat perbedaan kemampuan pemahaman matematik sebelum dan sesudah diberikan pembelajaran dengan model pembelajaran kontekstual “. Metode yang digunakan dalam penelitian ini adalah metode Pre-Experimental Design dengan bentuk One Group Pretest- Posttest Design. Sampel dalam penelitian ini adalah siswa kelas V dengan jumlah peserta didik 34 orang Instrumen yang digunakan dalam penelitian ini adalah soal tes pemahaman matematik. Berdasarkan hasil penelitian, pengolahan data dan analisis data yang dibantu dengan SPSS 16 nilai signifikansi 0.000 kurang dari alpha yang ditentukan yaitu 0,05 dengan demikian Ho ditolak sehingga dapat disimpulkan bahwa terdapat perbedaan kemampuan pemahaman matematik siswa sebelum dan sesudah pembelajaran menggunakan model pembelajaran kontekstual.
\end{abstract}

Kata kunci: Pemahaman Matematik, Model Pembelajaran Kontekstual, Materi Volume Kubus dan Balok

\footnotetext{
${ }^{1}$ Penulis adalah dosen tetap Prodi Pend. Matematika Fakultas Pendidikan Dasar dan Menengah Universitas Majalengka 


\section{A. Pendahuluan}

Perubahan masyarakat dewasa ini semakin cepat, yang ditandai oleh banyaknya temuan-temuan baru dalam berbagai bidang. Salah satu upaya untuk menyeimbanginya adalah dengan meningkatkan kualitas sumber daya manusia, diantaranya dengan meningkatkan kualitas pendidikan. Oleh karena itu, diantara upaya untuk membenahi, memperbaiki serta meningkatkan kualitas pendidikan dilihat dari sisi guru. Menurut Amri, Sofan dan Iif Khoiru Ahmadi (2010:2) "Sebagai salah satu komponen dalam Kegiatan Belajar Mengajar (KBM), guru memiliki posisi yang menentukan keberhasilan pembelajaran, karena fungsi utama guru ialah merancang, mengelola, dan mengevaluasi pembelajaran"

Sejalan dengan hal itu, guru akan menentukan kedalaman dan keluasan materi pelajaran, serta memilah dan memilih bahan pelajaran yang akan disajikan kepada peserta didik. Amri, Sofan dan Iif Khoiru Ahmadi (2010:3) mengemukakan "Guru hanya berpeluang untuk memanipulasi strategi atau metode pembelajaran di bawah karakteristik tujuan pembelajaran dan siswa". Berdasarkan pendapat tersebut, guru dituntut untuk dapat memperhatikan kebutuhan dan perbedaan peserta didik, mengembangkan strategi pembelajaran yang memungkinkan peserta didik aktif, kreatif dan menyenangkan, serta menilai proses dan hasil pembelajaran peserta didik secara akurat.

Matematika merupakan salah satu ilmu dasar yang memiliki peranan penting dalam pengembangan ilmu pengetahuan dan teknologi. Kita sebagai manusia harus menjadikan matematika sebagai dasar untuk dapat menguasai teknologi, sehingga menuntut sumber daya saing yang handal dan mampu berkompetisi secara global dengan melibatkan pemikiran kritis, sistematis, logis, rasional, kretaif dan mempunyai kemampuan kerja sama yang efektif. Cara berpikir demikian dapat dikembangkan melalui belajar matematika. Menurut Gravemeijer (Suharta, I Gusti Putu, 2001: 2) "Matematika sebagai aktivitas manusia, berarti manusia harus diberi kesempatan untuk menemukan kembali ide dan konsep matematika dengan bimbingan orang dewasa." Hal ini dapat diterapkan mulai anak duduk di sekolah dasar.

Sebagian peserta didik menganggap pelajaran matematika itu pelajaran yang sulit. Matematika dapat dianggap sukar dilihat dari hasil belajar yang bervariasi setelah proses pembelajaran dilaksanakan. Selain itu dalam proses pembelajaran pun matematika tidak bisa dipahami hanya dengan membaca materi atau mendengarkan penjelasan dari guru semata, harus disertai dengan latihan soal. Sesuai dengan hakikat matematika yang abstrak, mempelajarinya membutuhkan cara belajar yang tepat agar metematika dapat dipelajari dengan baik oleh peserta didik, sehingga pembelajaran yang dicapai sisuai dengan apa yang diharapkan. Hal serupa diungkapkan oleh Ruseffendi E.T. (2006:157) yang mengatakan, "Matematika dianggap sebagai ilmu yang sukar, rumit, dan memperdayakan". Disetiap pembelajaran, tidak semua proses pembelajaran dapat mencapai tujuan yang diharapkan. Banyak kendala yang dihadapi sehingga efisiensi dan 
efektivitas kegiatan pembelajaran tidak terwujud. Peserta didik sebagai generasi penerus bangsa untuk menjadi SDM yang unggul dan berkualitas, akan tetapi kenyataannya tujuan tersebut belum tercapai sepenuhnya. Salah satu kemampuan yang harus dimiliki oleh siswa dalam matematika adalah kemampuan pemahaman matematik.

Kemampuan pemahaman matematik adalah salah satu tujuan penting dalam pembelajaran, memberikan pengertian bahwa materimateri yang diajarkan kepada siswa bukan hanya sebagai hafalan, namun lebih dari itu dengan pemahaman siswa dapat lebih mengerti akan konsep materi pelajaran itu sendiri. Pemahaman matematik merupakan salah satu tujuan dari setiap materi yang disampaikan oleh guru, sebab guru merupakan pembimbing siswa untuk mencapai konsep yang diharapkan. Hal ini sesuai dengan Hudoyo (Herdian, 2010:1) yang menyatakan: "Tujuan mengajar adalah agar pengetahuan yang disampaikan dapat dipahami peserta didik". Pendidikan yang baik adalah usaha yang berhasil membawa siswa kepada tujuan yang ingin dicapai yaitu agar bahan yang disampaikan dipahami sepenuhnya oleh siswa.

Pemahaman merupakan terjemahan dari istilah understanding yang diartikan sebagai penyerapan arti suatu materi yang dipelajari. Lebih lanjut Michener (Herdian, 2010:1) menyatakan bahwa pemahaman merupakan salah satu aspek dalam Taksonomi Bloom. Pemahaman diartikan sebagai penyerapan arti suatu materi bahan yang dipelajari.

Rusefendi E.T (2006:221) menyatakan ada tiga macam pemahaman matematik, yaitu : pengetahuan (translation), pemberian arti (interpretasi) dan pembuatan ekstrapolasi (ekstrapolation). Pemahaman translasi digunakan untuk menyampaikan informasi dengan bahasa dan bentuk yang lain dan menyangkut pemberian makna dari suatu informasi yang bervariasi. Interpolasi digunakan untuk menafsirkan maksud dari bacaan, tidak hanya dengan kata-kata dan frase, tetapi juga mencakup pemahaman suatu informasi dari sebuah ide. Sedangkan ekstrapolasi mencakup estimasi dan prediksi yang didasarkan pada sebuah pemikiran, gambaran kondisi dari suatu informasi, juga mencakup pembuatan kesimpulan dengan konsekuensi yang sesuai dengan informasi jenjang kognitif ketiga yaitu penerapan (application) yang menggunakan atau menerapkan suatu bahan yang sudah dipelajari ke dalam situasi baru, yaitu berupa ide, teori atau petunjuk teknis.

Bloom mengklasifikasikan pemahaman (Chomprehension) ke dalam jenjang kognitif kedua yang menggambarkan suatu pengertian, sehingga siswa diharapkan mampu memahami ide-ide matematika bila mereka dapat menggunakan beberapa kaidah yang relevan. Dalam tingkatan ini siswa diharapkan mengetahui bagaimana berkomunikasi dan menggunakan idenya untuk berkomunikasi. Dalam pemahaman tidak hanya sekedar memahami sebuah informasi tetapi termasuk juga keobjektifan, sikap dan makna yang terkandung dari sebuah informasi. Dengan kata lain seorang siswa dapat mengubah suatu informasi yang ada dalam pikirannya kedalam bentuk lain yang lebih berarti.

Menurut Herdian (2010:1) "Pemahaman matematik merupakan salah satu tujuan dari setiap materi yang 
disampaikan oleh guru, sebab guru merupakan pembimbing siswa untuk mencapai konsep yang diharapkan". Berdasarkan pendapat tersebut, materimateri yang diajarkan kepada peserta didik bukan hanya sebagai hapalan, namun lebih dari itu dengan pemahaman peserta didik dapat lebih mengerti dan memahami akan konsep materi pelajaran itu sendiri.

Pemahaman matematik yang dimaksud dalam penelitian ini adalah pemahaman menurut Skemp (Sumarmo, Utari, 2010:5) yaitu pemahaman instrumental dan pemahaman relasional. Pada pemahaman instrumental, peserta didik memiliki kemampuan menggunakan konsep secara langsung, yaitu peserta didik tahu atau hapal rumus dan algoritma atau urutan pengerjaan dalam menyelesaikan soal. Sedangkan pemahaman relasional merupakan pemahaman yang lebih luas karena peserta didik tidak hanya tahu dan hapal rumus tetapi tahu bagaimana dan mengapa rumus atau cara itu dapat digunakan.

Polya (Sumarmo, Utari, 2006 : 4) merinci kemampuan pemahaman pada empat tahap, yaitu :

1. Pemahaman mekanikal yang dicirikan oleh mengingat dan menerapkan rumus secara rutin dan menghitung secara sederhana.

2. Pemahaman induktif : menerapkan rumus atau konsep dalam kasus sederhana atau dalam kasus serupa.

3. Pemahaman rasional : membuktikan kebenaran suatu rumus dan teorema.

4. Pemahaman intuitif : memperkirakan kebenaran dengan pasti (tanpa raguragu) sebelum menganalisa lebih lanjut.

Berbeda dengan Polya, menurut Pollastek (Sumarmo, Utari, 2006 : 4) pemahaman digolongkan ke dalam dua jenis, yaitu :

1. Pemahaman Komputasional : menerapkan rumus dalam perhitungan sederhana dan mengerjakan perhitungan secara algoritmik.

2. Pemahaman Fungsional : mengaitkan suatu konsep atau prinsip dengan konsep atau prinsip lainnya, dan menyadari proses yang dikerjakannya.

Skemp (Sumarmo, Utari, 2006 : 5) menggolongkan pemahaman dalam dua jenis, yaitu :

1. Pemahaman Instrumental : hafal konsep atau prinsip tanpa kaitan dengan yang lainnya, dapat menerapkan rumus dalam perhitungan sederhana, dan mengerjakan perhitungan secara algoritmik.

2. Pemahaman Relasional : mengaitkan satu konsep atau prinsip dengan konsep atau prinsip lainnya.

Copeland (Sumarmo, Utari, 2006 : 5) menggolongkan pemahaman dalam dua jenis, yaitu : "(a) Knowing how to : mengerjakan suatu perhitungan secara rutin atau algoritmik, (b) Knowing : mengerjakan suatu perhitungan secara sadar". Berdasarkan beberapa pendapat mengenai kemampuan pemahaman matematik yang telah diuraikan sebelumya, maka pemahaman yang di lakukan dalam penelitian ini dibatasi dalam pemahaman instrumental dan pemahaman relasional. Pemahaman instrumental yaitu peserta didik hapal dan dapat mengunakan rumus untuk menyelesaikan suatu soal dan pemahaman relasional yaitu siswa tidak hanya tahu dan hapal rumus tetapi peserta didik juga harus tahu bagaimana dan mengapa rumus digunakan. 
Berbagai macam metode dan model-model pembelajaran diujicobakan khususnya dalam budang matematika demi tercapainya prestasi belajar yang memuaskan sehingga kualitas sumber daya manusia meningkat. Hal itu karena matematika memegang peranan penting dalam kehidupan sehari-hari juga sebagai pendukung keberhasilan bidang ilmu lainnya atau kemajuan ilmu pengetahuan dan teknologi (IPTEK).

Upaya yang perlu dilakukan dalam menciptakan pembelajaran untuk meningkatkan aktivitas peserta didik, dan mengembangkan kemampuan pemahaman matematik peserta didik adalah memilih model pembelajaran yang relavan, salah satunya dengan menerapkan model pembelajaran yang menekan pada pemecahan masalah sebagai titik tolak untuk mengembangkan kemampuan pemahaman matematik. Model pembelajaran yang dirasa tepat untuk meningkatkan keaktifan peserta didik di kelas yaitu dengan menggunakan model pembaelajaran kontekstual. Pendekatan kontekstual merupakan pendekatan yang memungkinkan peserta didik menguatkan, memperluas dan menerapkan pengetahun dan keterampilan akademik mereka dalam berbagai macam tatanan kehidupan baik diseklah maupun diluar sekolah.

Pembelajaran kontekstual (Contextual Teaching and Learning) adalah konsep belajar yang membantu guru mengaitkan antara materi yang diajarkan dengan situasi dunia nyata siswa dan mendorong siswa membuat hubungan antara pengetahuan yang dimilikinya dengan penerapannya dalam kehidupan mereka sehari-hari. Menurut Suherman, Erman (2002:5) menyatakan bahwa terdapat 7 prinsip utama dalam pembelajaran kontekstual, yaitu:

1. Kontruktivisme (Contructivism)

Contructivism (kontruktivisme) merupakan landasan berfikir (filosofi) dari pendekatan kontekstual, yaitu bahwa pengetahuan dibangun oleh manusia sedikit demi sedikit, yang hasilnya diperluas melalui konteks yang terbatas (sempit) dan tidak sekonyongkonyong. Pengetahuan bukanlah seperangkat fakta-fakta, konsep atau kaidah yang siap untuk diambil dan diingat. Manusia harus mengkonstuksi pengetahuan itu dan memberi makna melalui pengamatan nyata.

Konstruktivisme dalam pembelajaran matematika misalnya, peserta didik dapat mengelompokan sendiri contoh himpunan dalam bentuk diagram Venn. Peserta didik akan mengkonstruksi pengetahuannya, sehingga ia bisa mentukan mana irisan dan mana gabungan.

\section{Menemukan (Inquiry)}

Menemukan merupakan bagian inti dari kegiatan pembelajaran berbasis kontekstual. Pengetahuan dan keterampilan yang diperoleh peserta didik diharapkan bukan hasil mengingat seperangkat fakta-fakta tetapi hasil menemukan sendiri. Guru harus selalu merancang kegiatan yang merujuk pada kegiatan menemukan, apapun materi yang diajarkan. Siklus inkuiri adalah: 1) Observasi (Observation); 2) Bertanya (Questioning); 3) Mengajukan dugaan (Hiphotesis); 4) Pengumpulan data (Data Gathering); 5) Penyimpulan (Conclussion).

Inkuiri dapat diterapkan pada semua bidang studi, termasuk matematika. Misalnya, peserta didik menemukan sendiri rumus dari irisan dan gabungan pada diagram Venn 
berdasarkan pengetahuan yang peserta didik miliki sebelumnya. Peserta didik akan merasakan kepuasan tersendiri jika ia berhasil melakukan penemuan.

\section{Bertanya (Questioning)}

Pengetahuan yang dimiliki seseorang, selalu bermula dari "bertanya". Questioning merupakan strategi utama pembelajaran yang berbasis kontekstual. Bertanya dalam pembelajaran dipandang sebagai kegiatan guru untuk mendorong, membimbing, dan menilai kemampuan berfikir peserta didik.

Dalam sebuah pembelajaran yang produktif, kegiatan bertanya berguna untuk: 1) Menggali informasi, baik administrasi maupun akademis; 2) Mengecek pemahaman siswa; 3) Membangkitkan respon kepada siswa; 4) Mengetahui sejauh mana keingintahuan siswa; 5) Mengetahui hal-hal yang sudah diketahui siswa; 6) Memfokuskan perhatian siswa pada sesuatu yang dikehendaki guru; 7) Untuk membangkitkan lebih banyak lagi pertanyaan dari siswa; 8) Untuk menyegarkan kembali pengetahuan siswa.

Konsep matematika saling berkaitan satu sama lain. Guru dapat menggunakan kegiatan bertanya untuk memotivasi peserta didik yaitu menghubungkan materi yang akan dipelajari dengan materi sebelumnya. Misalnya, untuk mempelajari irisan dan gabungan pada diagram Venn peserta didik harus memahami dahulu tentang himpunan. Untuk mengetahui hal ini guru dapat mengajukan berbagai pertanyaan kepada peserta didik. Selain dari guru, kegiatan bertanya juga dapat dilakukan dari peserta didik ke guru atau dari peserta didik ke peserta didik ketika mengalami kesulitan dalam memecahkan soal matematika.

4. Masyarakat Belajar (Learning Community)

Konsep lerning community menyarankan agar hasil pembelejaran diperoleh dari kerjasama dengan orang lain. Hasil belajar diperoleh dari "sharing" antar teman, antar kelompok, dan antara yang tahu ke yang belum tahu. Di ruang ini, di kelas ini, di sekitar ini, juga orang-orang yang ada diluar sana, semua anggota masyarakat belajar. Dalam kelas pembelajaran kontekstual, guru disarankan selalu melaksanakan pembelajaran dalam kelompokkelompok belajar. Peserta didik dibagi dalam kelompok-kelompok belajar yang anggotanya heterogen. Yang pandai mengajari yang lemah, yang tahu memberi yang belum tahu, yang cepat menangkap mendorong temannya yang lambat, yang mempunyai gagasan segera memberi usul, dan seterusnya. Vygotsky (Wartono, et.al. 2004:19) mengemukakan bahwa siswa belajar melalui interaksi dengan orang dewasa atau teman sebaya yang lebih mampu. Hal ini sejalan dengan ide Blancard (Wartono, et.al. 2004:19) bahwa strategi CTL mendorong siswa belajar dari sesama teman dan belajar bersama.

Peserta didik lebih mudah menemukan dan memahami konsepkonsep yang sulit jika mereka saling mendiskusikan masalah tersebut dengan temannya. Peserta didik bisa kerja sama dengan peserta didik lain untuk menemukan rumus dan konsep matematika yang sulit. Mereka menyatukan pendapat dan pengetahuan anatara konsep yang satu dengan konsep yang lain dalam matematika dengan berdiskusi untuk memperoleh suatu kesimpulan. 


\section{Pemodelan (Modeling)}

Komponen pembelajaran kontekstual selanjutnya adalah pemodelan. Maksudnya, dalam sebuah pembelajaran keterampilan atau pengetahuan tertentu, ada model yang bisa ditiru. Model itu bisa berupa cara mengoperasikan sesuatu, cara melempar bola dalam olahraga, contoh karya tulis, cara melafalkan bahasa inggris, dan sebagainya. Dalam pendekatan pembelajaran kontekstual, guru bukan satu-satunya model. Model dapat dirancang dengan melibatkan peserta didik.

Guru dapat memberi contoh tentang cara bekerja sesuatu, sebelum peserta didik melaksanakan tugas. Misalnya, cara menggambar diagram Venn dengan menggunakan penggaris dan jangka. Ketika guru mendemostrasikan cara menggambar, peserta didik mengamati langkahlangkah dan gerakan penggunaan penggaris dan jangka yang benar oleh guru. Sehingga peserta didik tahu bagaimana cara menggambar diagram Venn yang baik dan benar dengan menggunakan penggaris dan jangka. Dalam kasus ini guru menjadi model.

\section{Refleksi (Reflecsion)}

Refleksi juga bagian penting dalam pembelejaran dengan pendekatan kontekstual. Refleksi adalah cara berpikir tentang apa yang baru dipelajari atau berpikir kebelakang tentang apa-apa yang sudah kita lakukan dimasa lalu. Peserta didik mengendapkan apa yang merupakan pengayaan atau revisi dari pengetahuan sebelumnya. Refleksi merupakan respon terhadap kejadian, aktivitas atau pengetahuan yang baru diterima.

The Washington State Consortium For Contextual Teaching and Learning (Wartono, et.al. 2004:17) mengatakan bahwa proses refleksi yakni:

1. cara-cara berpikir tentang apa yang telah dipelajari.

2. Merevisi dan merespon kepada kejadian, aktivitas, dan pengalaman.

3. Mencatat apa yang telah kita pelajari, bagaimana kita merasakan ide-ide baru.

4. Dapat berupa berbagai bentuk: jurnal, diskusi, maupun hasil karya/seni.

Setelah pembelajaran berlangsung, peserta didik diberi kesempatan untuk merefleksi hasil belajar yang telah dilakukan. Misalnya, setelah peserta didik membuat gambar diagram Venn peserta didik diminta untuk merefleksi diri terhadap hasil karyanya. Apakah gambar diagram Venn yang telah dibuat sudah tepat berdasarkan konsep yang ada. Bagaimana cara membuat diagram Venn yang baik dan benar. Refleksi ini juga bisa dilakukan dengan membandingkan hasil pekerjaannya dengan pekerjaan teman sekelasnya. Sehingga ia bisa tahu apa kekurangan dari hasil karyanya.

7. Penilaian yang Sebenarnya
(Authentic Assesment)
Assesment adalah proses pengumpulan berbagai data yang bisa memberikan gambaran perkembangan belajar siswa. Gambaran perkembangan belajar siswa perlu diketahui oleh guru agar bisa memastikan bahwa siswa mengalami proses pembelajaran yang benar. Apabila data yang dikumpulkan guru mengidentifikasikan bahwa siswa mengalami kemacetan dalam belajar, maka guru segera mengambil tindakan yang tepat agar siswa terbatas dari kemacetan belajar. 
Penelitian dapat dilakukan oleh semua guru bidang studi, termasuk guru matematika. Penilaian ini tidak sebatas tes tertulis saja. Guru dapat menilai peserta didik selama proses pembelajaran berlangsung, bagaimana kegiatan yang dilakukan, keaktifan peserta didik ketika melakukan kegiatan, menemukan rumus atau konsep matematika, mendemonstrasikan dan menggunakan konsep tersebut untuk menghadapi soal-soal latihan

Kelebihan dan kekurangan pada pembelajaran kontekstual menurut Salma, Dewi Prawiradilaga dan Eveline Siregar (2004:22) adalah:

1. Kelebihan

Pembelajaran menjadi lebih bermakna dan riil. Artinya peserta didik dituntut untuk dapat menagkap hubungan antara pengalaman belajar di sekolah dengan kehidupan nyata. Hal ini sangat penting, sebab dengan dapat mengorelasikan materi yang ditemukan dengan kehidupan nyata, bukan saja bagi peserta didik materi itu akan berfungsi secara fungsional, akan tetapi materi yang dipelajarinya akan tertanam erat dalam memori peserta didik, sehingga tidak akan mudah dilupakan.

Pembelajaran lebih produktif dan mampu menumbuhkan penguatan konsep kepada peserta didik karena metode pembelajaran CTL menganut aliran konstruktivisme, dimana peserta didik dituntun untuk menemukan pengetahuannya sendiri. Melalui landasan filosofis konstruktivisme peserta didik diharapkan belajar melalui "mengalami" bukan "menghafal".

\section{2 . Kekurangan}

Guru lebih intensif dalam membimbing. Karena dalam metode CTL. Guru tidak lagi berperan sebagai pusat informasi. Tugas guru adalah mengelola kelas sebagai sebuah tim yang bekerja bersama untuk menemukan pengetahuan dan ketrampilan yang baru bagi peserta didik. Peserta didik dipandang sebagai individu yang sedang berkembang. Kemampuan belajar seseorang akan dipengaruhi oleh tingkat perkembangan dan keluasan pengalaman yang dimilikinya. Dengan demikian, peran guru bukanlah sebagai instruktur atau " penguasa " yang memaksa kehendak melainkan guru adalah pembimbing peserta didik agar mereka dapat belajar sesuai dengan tahap perkembangannya.

Guru memberikan kesempatan kepada peserta didik untuk menemukan atau menerapkan sendiri ide-ide dan mengajak peserta didik agar dengan menyadari dan dengan sadar menggunakan strategi-strategi mereka sendiri untuk belajar. Namun dalam konteks ini tentunya guru memerlukan perhatian dan bimbingan yang ekstra terhadap peserta didik agar tujuan pembelajaran sesuai dengan apa yang diterapkan semula. Berdasrkan uraian dari latar belakang masalah tersebut, maka tujuan dari penelitian ini adalah untuk mengetahui apakah terdapat perbedaan kemampuan pemahaman matematik siswa sebelum dan sesudah diberikan pembelajaran dengan model pembelajaran kontekstual

\section{B. Metodologi Penelitian}

Penelitian ini dilakukan pada siswa kelas V SDN Sukarasa II Kabupaten Garut Tahun Pelajaran 20142015. Populasi yang digunakan dalam penelitian ini adalah siswa kelas V SDN Sukarasa II. Adapun teknik pengambilan sampel dalam penelitian ini adalah dengan menggunakan teknik sampling purposive yaitu teknik penentuan sampel 
dengan pertimbangan tertentu (Sugiyono, 2009: 124). Teknik ini sangat cocok untuk digunakan dalam penelitian ini karena jumlah sampel yang diambil hanya pada siswa kelas $\mathrm{V}$ dengan mempertimbangkan kelas $\mathrm{V}$ sudah memahami dan mudah untuk diarahkan pada model pembelajaran tertentu.

Penelitian ini dilakukan dengan menggunakan pendekatan kuantitatif. Metode penelitian kuantitatif dapat diartikan sebagai metode penelitian yang berlandaskan pada filsafat positivisme, digunakan untuk meneliti pada populasi atau sampel tertentu, teknik pengambilan sampel pada umumnya dilakukan secara random, pengumpulan data menggunakan instrumen penelitian, analisis data bersifat kuantitatif/statistik dengan tujuan untuk menguji hipotesis yang telah ditetapkan (Sugiyono, 2009:14).

Metode yang digunakan dalam penelitian ini adalah metode eksperimen dengan bentuk Pre-Experimental Design. Dalam desain eksperimen ini tidak adanya variabel kontrol (kelas kontrol) dan tidak dipilih secara random. Dikatakan pre-experimental design karena desain ini belum merupakan eksperimen sungguh- sungguh, karena masih terdapat variabel luar yang ikut berpengaruh terhadap terbentuknya variabel dependen. Jadi, hasil eksperimen yang merupakan variabel dependen itu bukan semata - mata dipengaruhi oleh vareiabel independen (Sugiyono, 2009:109). Secara lebih terperinci pada penelitian ini, peneliti menggunakan Pre-Experimental Design dengan bentuk One Group PretestPosttest Design.

Penelitian dengan menggunakan model Pre-Experimental Design dengan bentuk One Group Pretest-Posttest Design mengandung paradigma bahwa terdapat suatu kelompok diberi treatment / perlakuan dan selanjutnya diobservasi hasilnya, akan tetapi sebelum diberi perlakuan terdapat pretest untuk mengetahui kondisi awal. Dengan demikian, hasil perlakuan dapat lebih akurat karena dapat membandingkan dengan keadaan sebelum diberi perlakuan.

Alur dari penelitian ini adalah kelas yang digunakan kelas penelitian (kelas eksperimen) diberi pre-test (O1) kemudian dilanjutkan dengan pemberian perlakuan/treatment $\left(\mathrm{O}_{2}\right) \quad$ yaitu penggunaan model pembelajaran kontekstual setelah itu diberi post-test. Secara sederhana desain penelitian dapat dilihat pada Tabel 1 berikut :

Tabel 1 Desain Penelitian One-Group Pre test - Post test Design

\begin{tabular}{|c|c|c|}
\hline Pre-Test & Treatment & Post-Test \\
\hline O1 & X & 02 \\
\hline
\end{tabular}

Instrumen penelitian merupakan suatu alat yang digunakan untuk mengukur nilai variabel yang diteliti dan mengumpulkan data - data selama penelitian dilakukan. Instrumen yang digunakan dalam pengambilan data primer pada penelitian ini dengan menggunakan tes kemampuan pemahaman matematik (pre-test dan post-test). 
1. Lembar soal pre test (tes awal sebelum mendapat perlakuan)

Soal - soal yang diberikan diambil dari bank soal yang sudah teruji validitas dan realibilitasnya.

2. Lembar soal post test (tes akhir setelah mendapat perlakuan)

Soal - soal yang diberikan diambil dari bank soal yang sudah teruji validitas dan realibilitasnya.

Sebelum instrumen tes digunakan, terlebih dahulu dilakukan pengujian soal agar data yang diperoleh baik dan dapat membuktikan hipotesis yang diajukan. Menurut Arikunto (2010:211) instrumen yang baik harus memenuhi dua persyaratan penting yaitu valid dan reliable. Untuk memperoleh data yang diperlukan maka dilakukan teknik pengumpulan data. Dalam melaksanakan penelitian ini ada beberapa teknik pengumpulan data yang dilakukan peneliti, antara lain :

1. Studi pendahuluan, dilakukan sebelum kegiatan penelitian dilaksanakan. Maksud dan tujuan dari kegiatan studi pendahuluan ini adalah untuk mengetahui beberapa hal antara lain: keadaan pembelajaran, keadaan siswa dan lain sebagainya

2. Studi literatur, dilakukan untuk mendapatkan informasi dengan memanfaatkan literatur yang relevan dengan penelitian ini

3. Tes, merupakan alat atau prosedur yang digunakan untuk mengetahui atau mengukur sesuatu dalam suasana, dengan cara dan aturan - aturan yang sudah ditentukan (Arikunto, 2010: 53). Penelitian ini menggunakan tes berupa tes uraian. Tes dilaksanakan pada saat pre-test dan post-test. Pretest atau test awal diberikan dengan tujuan mengetahui kemampuan awal subjek penelitian. Sementara post-test atau test akhir diberikan dengan tujuan untuk melihat perubahan atau peningkatan penguasaan materi siswa setelah menggunakan model pembelajaran kontekstual. Pada penelitian ini, tes merupakan data primer atau data utama.

Analisis data yang akan dilaksanakan berdasarkan rumusan masalah secara umum yaitu mengetahui apakah penggunaan model pembelajaran kooperatif tipe GI berpengaruh terhadap kemampuan kognitif siswa daripada yang menggunakan pembelajaran konvensional. Analisis data yang dilakukan oleh peneliti dibantu dengan micosoft excel dan SPSS 16. Ada tiga perlakuan dalam teknik analisis data, yaitu :

Tes normalitas menggunakan SPSS yaitu dengan uji Shapiro Wilk, (jika tidak normal menggunakan uji non parametric. Bila data tidak normal, maka statistik parametrik tidak dapat digunakan untuk itu perlu digunakan statistik nonparametrik (Sugiyono, 2013: 79). Penggunaan statistik parametris mensyaratkan bahwa data variabel yang akan dianalisis harus berdistribusi normal. Setelah semua data telah terpenuhi syaratnya untuk uji $\mathrm{t}$ paired sample $t$ tes, meliputi uji normalitas.

\section{Hasil Penelitian dan Pembahasan}

Penelitian dilaksanakan terhadap peserta didik kelas V SDN Sukarasa II Kabupaten Garut dengan menggunakan 
model pembelajaran kontekstual. Seperti yang telah dikemukakan bahwa tujuan penelitian ini adalah untuk mengetahui adakah adakah perbedaan kemampuan pemahaman matematik sebelum dan sesudah diberikan pembelajaran dengan menggunakan model pembelajaran kontekstual. Data kuantitatif diperoleh dari hasil tes pemahaman matematik.
Tes diberikan sebelum dan setelah pembelajaran dilaksanakan pada materi volume balok dan kubus. Data yang diperoleh dari penelitian diolah untuk memudahkan peneliti mengambil simpulan. Tes diberikan kepada 34 orang yang pembelajarannya menggunakan model pembelajaran kontekstual. Berikut ini disajikan mengenai data deskriptifnya

Tabel 2

Deskriptif Data Tes Pemahaman Matematika Sebelum dan Sesudah Pembelajaran

Kontekstual

Descriptive Statistics

\begin{tabular}{|l|r|r|r|r|r|r|r|r|}
\hline & & & & & & & $\begin{array}{c}\text { Std. } \\
\text { Deviation }\end{array}$ & Variance \\
\hline pre_tes & 34 & 6.00 & 4.00 & 10.00 & 219.00 & 6.4412 & 1.81227 & 3.284 \\
Post_tes & 34 & 11.00 & 9.00 & 20.00 & 476.00 & 14.0000 & 3.11400 & 9.697 \\
Valid N (listwise) & 34 & & & & & & & \\
\hline
\end{tabular}

Sumber:Pengolahan Data menggunakan SPSS 16

Berdasarkan data tersebut terlihat bahwa skor rata-rata sesudah pembelajaran lebih besar jika dibandingkan sebelum pembelajaran yaitu 14.00 untuk sesudah pembelajaran dan 6.44 untuk sebelum pembelajaran. Sebelum dilakukan uji hipotesis terlebih dahulu diuji prasyratnya sebagai berikut:

Tabel 2

Uji Normalitas Tes Pemahaman Matematika Sebelum dan Sesudah Pembelajaran Kontekstual

Tests of Normality

\begin{tabular}{|l|r|r|r|r|r|r|}
\hline & \multicolumn{3}{|c|}{ Kolmogorov-Smirnov $^{\text {a }}$} & \multicolumn{3}{c|}{ Shapiro-Wilk } \\
\cline { 2 - 7 } & \multicolumn{1}{|c|}{ Statistic } & \multicolumn{1}{c|}{$\mathrm{df}$} & \multicolumn{1}{c|}{ Sig. } & Statistic & \multicolumn{1}{c|}{ df } & \multicolumn{1}{c|}{ Sig. } \\
\hline pre_tes & .217 & 34 & .000 & .881 & 34 & .001 \\
Post_tes & .181 & 34 & .006 & .935 & 34 & .045 \\
\hline
\end{tabular}

a. Lilliefors Significance Correction

Sumber:Pengolahan Data menggunakan SPSS 16 
Uji normlaitas menggunakan uji Shapiro Wilk dengan alpha 5\% ternyata nilai signifikansi untuk pretes dan postes di bawah 0,05 dengan demikian sebaran data tidak normal. Karena sebaran data tidak normal maka dilakukan uji non paramterik yaitu uji wilcoxon dengan hasil sebagai berikut:

Tabel 3

Uji Wilcoxon Tes Pemahaman Matematika Sebelum dan Sesudah Pembelajaran Kontekstual

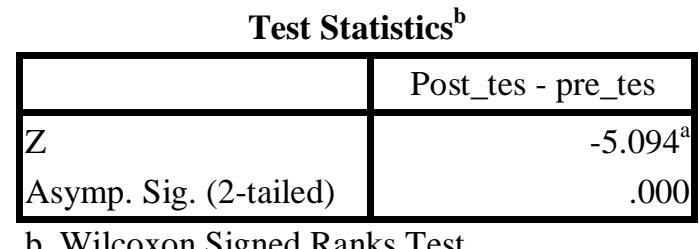

Berdarakan hasil tersebut terlihat bahwa nilai signifikansi 0.000 kurang dari alpha yang ditentukan yaitu 0,05 dengan demikian Ho ditolak sehingga dapat disimpulkan bahwa terdapat perbedaan kemampuan pemahaman matematik siswa sebelum dan sesudah pembelajaran menggunakan model pembelajaran kontekstual. Berdasarkan hasil penelitian dan pengujian hipotesis, terdapat perbedaan kemampuan pemahaman matematik siswa sebelum dan sesudah pembelajaran menggunakan model pembelajaran kontekstual. Hal ini disebabkan dalam pembelajaran kontektual peserta didik menggunakan kemampuan berfikir kritis, dengan metode tanya jawab, diskusi, pemberian tugas, peserta didik terlibat penuh dalam mengupayakan terjadinya proses pembelajaran yang efektif dan bekerja sama dengan kelompok heterogen, sharing pendapat dan pengetahuan. Dipilihnya kelompok heterogen adalah agar terjadi interaksi dan saling membantu antar peserta didik dalam menyelesaikan masalah. Hal ini sependapat dengan Lie, Anita (2008: 43)
"Kelompok heterogen memberikan kesempatan untuk saling mengajar (peer tutoring) dan saling mendukung. Disini guru membagikann bahan ajar kepada tiap-tiap kelompok, peserta didik diberi kesempatan menemukan dan membangun sendiri pemahamannya. Hal ini sesuai dengan teori belajar Bruner, yang menekankan pada penemuan peserta didik untuk membangun atau mengkontruksi pengetahuannya sendiri, dengan cara berdiskusi kelompok. Hal ini juga sejalan dengan teori Vygotsky yang menekankan pada interaksi sosial dalam membangun pengetahuan dan menggunakan tugas-tugas yang konstruktif. Peserta didik mampu mengembangkan kemampuan berfikirnya untuk memecahkan masalah dan menemukan konsep baru dari suatu masalah tersebut, guru berkeliling memberikan scaffolding dan menjadi fasilitator bagi peserta didik. Scaffolding adalah memberikan bantuan seperlunya kepada peserta didik yang membutuhkan. Sesuai dengan teori Vygotsky yang menyatakan bahwa diskusi kelompok guru berperan 
memberikan scaffolding. Selain itu, guru menekankan pada peserta didik untuk mengemukakan ide kelompoknya sendiri tentang cara menyelesaikan masalah. Kendala yang dihadapi dalam pembelajaran kontekstual diantaranya masih ada peserta didik yang malas memecahkan masalah yang tersedia. Peserta didik yang tidak memiliki minat yang tinggi dalam memecahkan masalah merasa kesulitan dalam belajar terutama dalam pemahaman relasional. Hal ini menyebabkan beberapa peserta didik yang kurang berpartisipasi dalam diskusi kelompok. Seiring berjalannya waktu, hal tersebut dapat diatasi. Dengan motivasi yang kuat dari guru dan teman sekelompok, dengan seperti itu peserta didik lebih semangat dalam belajar.

Maka dapat disimpulkan bahwa pemahaman matematik yang diperoleh melalui pembelajaran yang menggunakan model pembelajaran kontekstual dapat lebih meningkat. Hal ini sesuai dengan kelebihan pembelajaran kontekstual yang dikemukakan oleh Sabandar, Jozua (2003:4) antara lain :

1. Siswa akan belajar banyak dan akan mengingatnya lebih lama jika mereka dapat mengaitkan apa yang mereka pelajari itu pada kontekskonteks yang bermakna yang terdapat pada dunia nyata diluar kelas.

2. Belajar akan lebih optimal jika pembelajaran di kelas ditempatkan dalam suatu konteks, mengikutsertakan aktifitas-aktifitas autentik, serta apa yang dipelajari dapat ditransfer dalam kegiatan siswa di luar kelas, termasuk aplikasi dalam dunia nyata dan dimasyarakat
Berdasarkan simpulan hasil penelitian, maka peneliti menyarankan sebagai berikut :

1. Dalam proses belajar mengajar sebaiknya kepala sekolah menyarankan kepada setiap guru mata pelajaran agar mencoba menggunakan model pembelajaran kontekstual disamping menggunakan model pembelajaran yang biasa dilaksanakan di sekolah.

2. Sebaiknya guru mencoba menggunakan model pembelajaran kontekstual agar proses pembelajaran lebih kondusif dan menjalin kerjasama diantara peserta didik, disamping menggunakan model pembelajaran konvensional.

3. Untuk peneliti selanjutnya tertarik menerapkan model pembelajaran kontekstual hendaknya penelitian pada materi lainnya dan mengukur kemampuan yang berbeda seperti kemampuan komunikasi, penalaran, berfikir kritis dan kreatif matematik

\section{Bahan Rujukan}

Amri, Sofan dan Iif Khoiru Ahmadi. (2010). Proses Pembelajaran Kreatif dan Inovaif dalam Kelas. Jakarta: Prestasi Pustaka Publisher.

Arikunto, Suharsimi, (2010). Prosedur Penelitian Suatu Pendekatan Praktek, Jakarta: Penerbit Rineka Cipta

Herdian. (2010). KEMAMPUAN PEMAHAMAN MATEMATIK. [Online].

Tersedia:http://herdy07.wordpress.co m/2010/05/27/kemampuanpemahaman-matematis/ [Januari 2014] 
Lie, Anita. (2008). Cooperative Learning (Mempraktekan Cooperative Learning di Ruang-ruang Kelas). Jakarta : PT Grasindo

Ruseffendi, E.T. (2006). Pengantar Kepada Guru Mengembangkan Kompetensinya Dalam Pengajaran Matematika Untuk Meningkatkan CBSA. Bandung : Tarsito.

Sabandar, Josua. (2003). Pendekatan Kontekstual Dalam Pembelajaran Matematika. Bandung: Universitas Pendidikan Indonesia.

Salma, Dewi Prawiradilaga dan Eveline Siregar. (2004). Mozaik Teknologi Pendidikan. Jakarta: Prenada Media.

Sugiyono. (2009). Metode Penelitian Kuantitatif. Bandung : Alfabeta
Sugiyono. (2013). Statistika untuk Penelitian. Bandung: Alfabeta.

Suharta, I.G.P. (2004). Matematika Realistik: Apa dan Bagaimana? Editorial Jurnal Pendidikan dan Kebudayaan. Edisi 38. Depdiknas Jakarta.

Suherman, Erman. (2002). Pendekatan Kontekstual (Contextual Teaching and Learning). Jakarta: Depdiknas.

Sumarmo, Utari. (2010). Berfikir dan Disposisi Matematik: Apa, Mengapa, dan Bagaimana Dikembangkan pada Peserta Didik. Makalah FPMIPA UPI. Bandung: tidak diterbitkan.

Wartono, et.al. (2004). Materi Pelatihan Terintegrasi SAINS. Jakarta: Depdiknas. 